\title{
New species of Cenozoic benthic foraminifera from the former British Petroleum micropalaeontology collection
}

\author{
Lyndsey R. Fox ${ }^{1}$, Stephen Stukins ${ }^{1}$, Tom Hill ${ }^{1}$, and Haydon Bailey ${ }^{2}$ \\ ${ }^{1}$ Department of Earth Sciences, The Natural History Museum, Cromwell Road, London SW7 5BD, UK \\ ${ }^{2}$ Network Stratigraphic Consulting Ltd, Harvest House, Cranborne Road, Potters Bar EN6 3JF, UK
}

Correspondence: Lyndsey R. Fox (lyndsey.fox@nhm.ac.uk)

Published: 5 January 2018

\begin{abstract}
This paper describes four new Cenozoic, deep-water benthic foraminifera from the reference collections at the Natural History Museum in London. The focus is on selected calcareous taxa that are of stratigraphical and/or palaeoecological significance for academic and industrial-related activities.

Alabamina heyae (urn:lsid:zoobank.org:act:1E8A66E9-1F4C-4B61-BA97-6E0ECCD0173E), Nonion cepa (urn:lsid:zoobank.org:act:9F36350A-1E49-4D69-B2CC-C83F343E2952), Uvigerina kingi (urn:lsid:zoobank.org:act:C36C89C2-2E65-4FF6-9368-C169B4591995) and Lenticulina stewarti (urn:lsid:zoobank.org:act:485AE871-CECA-44E8-ABD1-BAE2961FFD59) are described with new illustrations. Their biostratigraphic and palaeoecological significance is briefly discussed.
\end{abstract}

\section{Introduction}

Museum collections often contain a wealth of unstudied material in need of attention. Combined with an industrial collection containing material from continuous deposits that is out of reach for the general scientist, the potential for discovery is great. The former British Petroleum micropalaeontology collection was acquired by the Natural History $\mathrm{Mu}-$ seum in London in 1992, when the collection was deemed surplus to requirements due to changes in the business practices at British Petroleum. This collection contains a vast and comprehensive array of material from approximately 3800 wells (exploration, appraisal and production) in association with $\sim 800$ outcrop sequences collected from the late 1950s until 1991. Associated with the well and outcrop sequences are individual taxonomic collections, such as Walter Blow's Cenozoic planktonic foraminifera collection (Blow, 1979). In this study the authors describe specimens from the regional reference collections that were collated by British Petroleum palaeontologists as they worked on particular regions and other specific projects. The specimens within these collections are mostly informal types that were used as references for the key biostratigraphical markers encountered in their routine analysis. Although there were attempts to put the cor- rect scientific name to the most of the taxa in these type collections, many were still left with open nomenclature.

The focus of this study is Cenozoic material from the northwestern European reference collection, more specifically the North Sea region, which constituted much of British Petroleum's business interests during the time that the collection was compiled. Following a recent reclassification of over 3000 slides and $\sim 33000$ specimens that form the NW European reference collection, a number of taxa were found in need of immediate formal classification, whilst others were identified that were in need of closer examination before formal descriptions are assigned. These latter taxa will be the focus of later studies.

This study presents four new benthic foraminiferal taxa from the Cenozoic that are formally described from the former British Petroleum micropalaeontology collection. These are significant due to their biostratigraphical and potentially palaeoenvironmental importance, both of which will be discussed.

\section{Materials}

The specimens are housed at the Natural History Museum in London as part of the former British Petroleum mi- 
cropalaeontology collection. The specimens were registered electronically during the recent reclassification through the Natural History Museum database, and details are available through the online portal at http://data.nhm.ac.uk. Specimens and material are available on request through the relevant curators. Many of the processed sample residues for the well runs are available; a spreadsheet with information is also available on request.

Light microscope images were taken using a Nikon SMZ25 stereoscopic zoom microscope and a Nikon DS-Fi2 digital camera. SEM images were taken using uncoated specimens on a LEO 1455 VP scanning electron microscope.

\section{Systematics}

We present systematic data (descriptions, synonymies, biogeography and palaeoecologies) that were assembled from primary research, the micropalaeontological literature and consultation with specialists. Brief geological context is also provided, where available, for the wells and outcrops in which the type specimens were found. The taxonomic classification follows Loeblich Jr. and Tappan (1987) with a few exceptions, which mainly reflect taxonomic updates published subsequently.

Order Rotaliida Lankester, 1885

Superfamily Chilostomelloidea Brady, 1881

Family Alabaminidae Hofker, 1951

Genus Alabamina Toulmin, 1941

Type species: Alabamina wilcoxensis Toulmin, 1941

Alabamina heyae n. sp.

Figs. 1.1-1.2

Alabamina sp. 19 internal British Petroleum report.

Diagnosis: Test small; forms small lenticular trochospire; nearly biconvex in cross section. The spiral side is evolute; the umbilical side involute with a closed umbilicus. The 5-6 crescent-shaped chambers in the final whorl gradually increase in size. Sutures are flush or slightly depressed, radial and slightly curved on the umbilical side. Chamber walls are calcareous and finely perforate. The primary aperture is an interiomarginal extraumbilical narrow slit with a thin lip. The diameter is between 100 and $150 \mu \mathrm{m}$.

Remarks: Alabamina heyae differs from Alabamina dissonata in the absence of a keel and the presence of fewer chambers in the final whorl.

Type level: Lower Chattian/Rupelian, Oligocene.
Type locality: Alzey and Kirchen in the Rhine Valley, Germany

Distribution: Currently restricted to the immediate area around the type locality, but believed to have a wider geographical distribution which has yet to be established.

Etymology: This species is named in honour of Gerry Hey, whose determination during her time as Global Technical Records Manager at BP was vital in implementing this study.

\section{Holotype: NHMUK PM PF 74488}

Paratype: NHMUK PM PF 74489

Superfamily Nonionoidea Schultze, 1854

Family Nonionidae Schultze, 1854

Genus Nonion de Montfort, 1808

Type species: Nautilus faba Fichtel \& Moll, 1798

Nonion cepa n. sp.

Fig. 1.5

Elphidium cf. latidorsatum (Reuss, 1864), p. 31, Plate 4, Figs. 3, 4

Nonion sp. A King, 1988, p. 480, Plate 9.8, Figs. 1, 2

Diagnosis: Test small; planispiral, chambers depressed, moderately inflated; periphery broadly rounded: 4-5 chambers in the last whorl; sutures radial, deeply incised; umbilicus deep, may be partly or wholly filled granular calcite, which extends over the apertural face and adjoining areas; where the aperture is visible it forms a basal slit. The diameter is $200 \mu \mathrm{m}$.

Remarks: The affinities of this species are uncertain. In gross morphology it resembles Elphidium latidorsatum (Reuss; see Murray and Wright, 1974, Plate 12, Fig. 1) but lacks the septal bridges of Elphidium. It is here assigned to Nonion; there is considerable similarity to $N$. parvulum (Grzybowski), as figured by Murray and Wright (1974, Plate 13, Figs. 14-15), but their specimen may be incorrectly referred to Grzybowski's species. It occurs commonly in probable bathyal environments in the central North Sea, often associated with the non-calcareous agglutinating foraminifera of the "Rhabdammina biofacies". This species was described by King $(1983,1989)$ and is used as a zonal marker for the late Oligocene (Zone NSB8) sediments from numerous wells in the North Sea. Six specimens exist in the BP NWE collection and given the stratigraphic importance of this taxon, there is considerable value in proceeding to a formal description of it. 

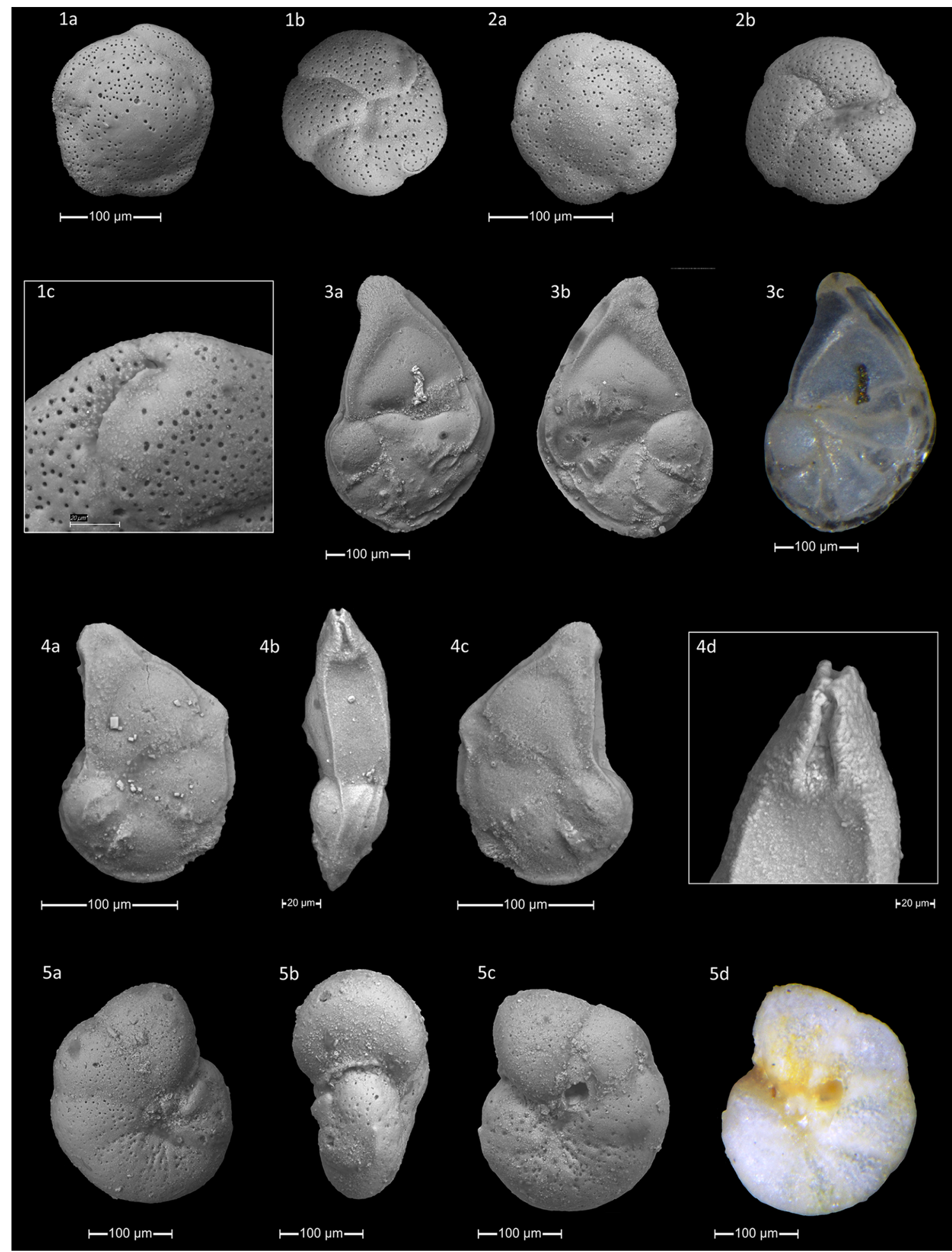

$\vdash 100 \mu \mathrm{m}-$

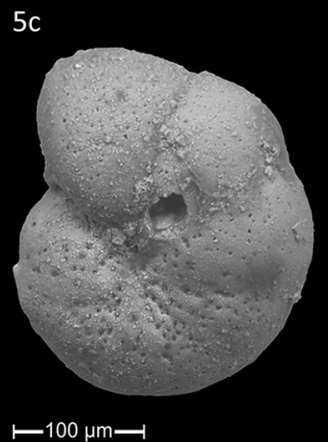

$5 d$

Figure 1. (1-2) Alabamina heyae n. sp.: (1) holotype (NHMUK PM PF 74488), (2) paratype (NHMUK PM PF 74489). (3-4) Lenticulina stewarti n. sp.: (3) holotype (NHMUK PM PF 74494), (4) paratype (NHMUK PM PF 74495). (5) Nonion cepa n. sp. holotype (NHMUK PM PF 74490). 


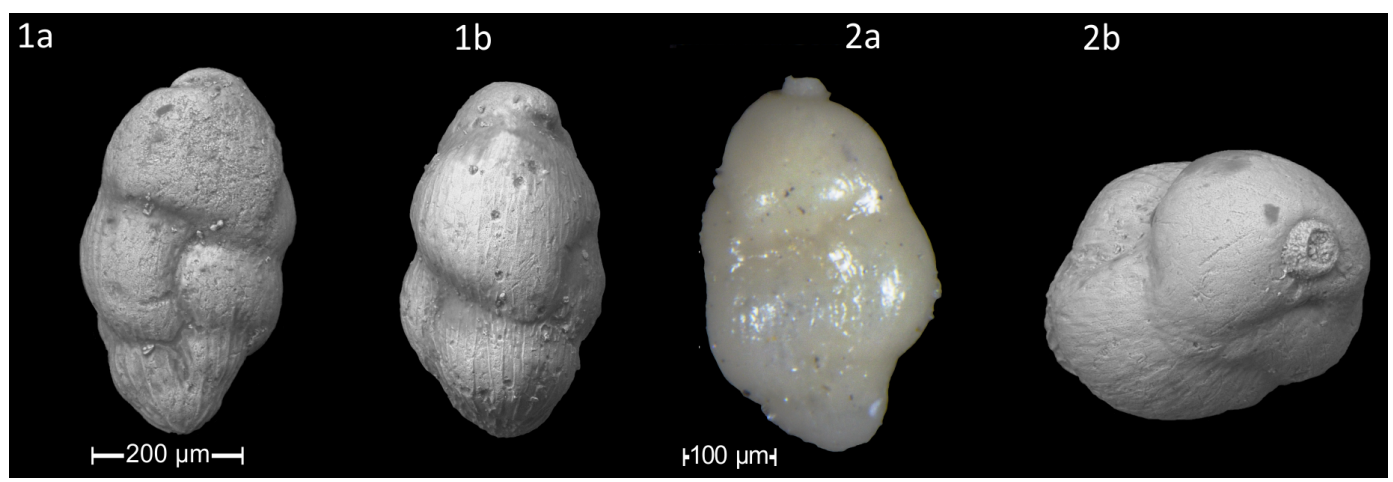

Figure 2. (1-2) Uvigerina kingi n. sp.: (1) holotype (NHMUK PM PF 74492), 2 paratype (NHMUK PM PF 74493).

Type level: Late Oligocene (Zone NSB8) to Early Miocene (Zone NSB9).

Type locality: Well: De Cocksdorp 1, onshore, Texel, nothern Netherlands.

Distribution: Commonly found in the central North Sea basin and onshore well sites of northwestern Europe.

Etymology: The easy-to-remember informal name of "Nonion onion" was used as a working name by the authors and therefore the Latin translation was adopted for the formal naming.

\section{Holotype: NHMUK PM PF 74490}

Paratype: NHMUK PM PF 74491

Superfamily Buliminoidea Jones, 1875

Family Uvigerinidae Haeckel, 1894

Genus Uvigerina d'Orbigny, 1826

Uvigerina kingi $\mathrm{n}$. sp.

Figs. 2.1-2.2

Uvigerina sp. cf. hemmooriensis Daniels and Spiegler, 1977, p. 23, Plate 2, Fig. 30

Uvigerina sp. cf. hemmooriensis King 1983, p. 27, Plate 2, Fig. 30

Uvigerina sp. A King, 1989, p. 481, Plate 9.9, Fig. 16

Diagnosis: Test large, triserial, broadly fusiform, chambers ornamented with around 6-8 thick rounded costae, tending to cross sutures; tending to become uniserial. The aperture is situated on a short smooth neck. Specimens generally uniform in size; length $\sim 400 \mu \mathrm{m}$, width $\sim 200 \mu \mathrm{m}$.
Remarks: This large and distinctive species has previously been referred to as $U$. cf. hemmooriensis by King (1989, p. 485) and is illustrated by King (1983, p. 26). This species is characteristic in a thin interval within the upper part of the Middle Miocene in the southern and central North Sea where it is usually associated with Siphonina reticulata. Its highest occurrence defines the top of benthic foraminifera Zone NSB12; this zone is recognizable in only the outer sublittoral-epibathyal biofacies of the central North Sea (King, 1983). Uvigerina kingi n. sp. does not conform with the descriptions of any other Miocene species or otherwise. U. kingi n. sp. differs from $U$. hemmooriensis (Daniels and Spiegler, 1977) by having fewer and more rounded ribs per whorl. $U$. kingi n. sp. also lacks an apertural tooth, which is characteristic for $U$. hemmooriensis.

Type level: Subzone NSB12c, Middle Miocene.

Type locality: Well: Obdam 1, onshore, the Netherlands.

Distribution: Found in the southern and central North Sea and onshore in the Netherlands.

Etymology: This species is named in memory of renowned Cenozoic North Sea biostratigrapher Chris King, who first described this taxon in 1983.

Holotype: NHMUK PM PF 74492

Paratype: NHMUK PM PF 74493

Order Lagenida Delage \& Hérouard, 1896

Superfamily Nodosarioidea Ehrenberg, 1838

Family Vaginulinidae Reuss, 1860

Subfamily Lenticulininae Chapman et al., 1934

Genus Lenticulina Lamarck, 1804

Type species: Lenticulina rotulata (Lamarck, 1804) 
Lenticulina stewarti $\mathrm{n}$. sp.

Figs. 1.3-1.4

\section{Lenticulina sp. 96 internal British Petroleum report}

Diagnosis: Test small, involute, planispiral, elongate in outline, and strongly compressed in cross section with a keeled periphery. The test consists of a single whorl containing 4-5 moderately inflated triangular chambers, increasing rapidly in size. Chambers are separated by slightly curved, flush or raised sutures fusing into a large umbilical boss. Keel becomes thicker in final chamber. Chamber walls are calcareous, perforate and smooth. The primary aperture is terminal and forms an elongated slot. Specimens range in size from 200 to $300 \mu \mathrm{m}$ in length and 100 to $150 \mu \mathrm{m}$ wide.

Remarks: Lenticulina stewarti n. sp. bears a resemblance to Vaginulinopsis mexicana but lacks the radiate aperture typical of this genus. This taxa was placed into the genus Lenticulina due to the "slot-like" terminal aperture.

Type level: Rupelian, Oligocene.

Type locality: Wiesloch, Germany.

Distribution: Currently restricted to the immediate area around the type locality, but believed to have a wider geographical distribution which has yet to be established.

Etymology: Named in honour of Dr Ian Stewart, Distinguished Exploration Advisor at BP, without whom this study could not have taken place.

\section{Holotype: NHMUK PM PF 74494}

Paratype: NHMUK PM PF 74495

\section{Summary}

This study highlights the importance of both museum and industrial collections for their vast potential for new publishable data, including new taxa and material from restricted and no-longer-accessible locations. Four new species of deep-water benthic foraminifera from the Cenozoic in northwestern Europe are described from the extensive reference collections at the Natural History Museum in London. These benthic foraminifera are important for their biostratigraphic and palaeoenvironmental value; hence their overdue and formalized taxonomic descriptions.

Data availability. Type and figured material is deposited at the Natural History Museum, London, where it available for inspection upon request.
Competing interests. The authors declare that they have no conflict of interest.

Acknowledgements. We are grateful to Iain Stewart and Gerry Hey for their continued support and enthusiasm towards the project and for providing vast amounts of BP literature. Further thanks go to Kelly Smith and Giancarlo Manna for providing the light microscope images of the BP reference collection. We are also grateful to our reviewers: Mike Kaminski and an anonymous reviewer, whose constructive comments greatly improved the paper. This research has been funded by BP Exploration (Sunbury, UK) through the project "A Re-appraisal of the BP Micropalaeontology Collection".

Edited by: Sev Kender

Reviewed by: Mike Kaminski and an anonymous reviewer

\section{References}

Blow, W. H.: The Cainozoic Globigerinida, Atlas, Brill Archive, 1979.

Brady, H. B.: Notes on some of the Reticularian Rhizopoda of the "Challenger" Expedition, Q. J. Microsc. Sci., 19, 20-62, 1881.

Chapman, F., Parr, W. J., and Collins, A. C.: Tertiary Foraminifera of Victoria, Australia. - The Balcombian Deposits of Port Phillip. Part III: Journal of the Linnean Society of London, Zoology, 38, 553-577, 1934.

Daniels, C. V. and Spiegler, D.: Uvigerinen (Foram.) im Neogen Nordwestdeutschlands (Das Nordwestdeutsche Tertiärbecken, Beitrag Nr. 23), Geologisches Jahrbuch, A, 40, 3-59, 1977.

Delage, Y. and Hérouard, E. J. É.: Traité de zoologie concrète, Librairie H. Le Soudier, p. 136, 1896

De Montfort, D. P.: Conchyliologie systematique et classification methodique des coquilles: Paris, F. Schoell, p. 211, 1808.

d'Orbigny, A. D.: Tableau méthodique de la classe des Céphalopodes, 7, 245-314, 1826.

Fichtel, L. V. and Moll, J. V.: Testacea microscopica aliaque minuta ex generibus Argonauta et Nautilus ad naturam delineata et descripta, A. Pichler, Wien, p. 103, 1798.

Haeckel, E.: Systematische Phylogenie: Entwurf eines natürlichen Systems der organismen auf Grund ihrer Stammesgeschichte, G. Reimer, 1894

Hofker, J.: The foraminifera of the Siboga Expedition, Brill, p. 513. 1951.

Jones, R.: The micrographic dictionary, edited by: Griffith, J. W. and Henfrey, A., London, van Voorst, p. 845, 1875.

King, C.: Cainozoic micropalaeontological biostratigraphy of the North Sea, Rep. Inst. Geol. Sci, 82/7, p. 26, 1983.

King, C.: Cenozoic of the North Sea, in: Jenkins, Stratigraphic Atlas of Fossil Foraminifera: Chichester, edited by: Jenkins, D. G. and Murray, J. M., Ellis Horwood Ltd, p. 485, 1989.

Lamarck, J. D.: Suite des mémoires sur les fossiles des environs de Paris, 179-188, 1804

Loeblich Jr., A. and Tappan, H.: Foraminiferal Genera and Their Classification: Van Nostrand Reinhold Company, New York, 2, p. $485,1987$. 
Murray, J. W. and Wright, C. A.: Palaeogene foraminiferida and palaeocology, Hampshire and Paris Basins and English Chammel. Spec. Pap. Palaentol., 14, 1-171, 1974.

Reuss, A. E. R.: Die marinen tertiärschichten Böhmens und ihre Versteinerungen, Aus der kk Hof-und staatsdruckerei, 207-285, 1860.

Reuss, A. E. R.: Die fossilen Foraminiferen, Anthozoen und Bryozoen von Oberburg in Steiermark, Denkschr. K. Akad. Wiss. Wien. Math.-Naturw., p. 10, 1864.
Schultze, M. J. S.: Über den Organismus der Polythalamien (Foraminiferen): nebst Bemerkungen über die Rhizopoden im Allgemeinen, mit 7 ill. Kupfertafeln, Engelmann, 143-152, 1854.

Toulmin, L. D.: Eocene smaller foraminifera from the Salt Mountain Limestone of Alabama, J. Paleontol., 15, 567-611, 1941. 